\title{
Acceptability, Equality, and Equity: A Fair Allocation Model for Scarce Healthcare Resources During Pandemics and Natural Disasters
}

\section{Kabull Edillebillirlilk, Eşitlilk ve Hakkaniyet: Pandemi ve Doğall Afetler Sırrasında Sınıılı Sağlık Kayıalklaııı İçin Adill Bir Tahsis Modeli}

\author{
Ercan AVCI $\dot{I}^{a}$
}

\begin{abstract}
The COVID-19 pandemic has necessitated revisiting the matter of allocating scarce healthcare resources. During pandemics and natural disasters, applying certain allocation methods is inevitable due to an uncontrollable surge in the need for scarce resources, and those methods should distribute potential benefits and burdens according to the principle of justice. This article briefly studies four allocation models and proposes a new approach to maximize total benefits with social and ethical acceptability, equality, and equitability. For accomplishing that goal, the Acceptability, Equality, and Equity (AEE) model recommends six principles, atransparency and equal treatment, $b$-objective assessment and supervision, $c$-sustaining ongoing treatments, $d$-priority to individuals performing crucial tasks, e-scoring system, and $f$-lottery for individuals with the same conditions. The AEE model suggests allocating scarce resources not only based on medical facts but also social and ethical considerations, such as sustaining ongoing medical procedures for patients who are undergoing medical treatment and winning public support through transparent, objective, and fair implications.
\end{abstract}

Keywords: Pandemics; natural disasters; scarce resources; acceptability; equality; equity

$-$

Özet: COVID-19 salgını, sınırlı sağlık kaynaklarının tahsisi konusunun yeniden gözden geçirilmesini gerektirmektedir. Pandemiler ve doğal afetler sırasında sınırl kaynaklara olan ihtiyacın hızlı bir biçimde artması nedeniyle belirli tahsis yöntemlerinin uygulanması kaçınılmazdır ve bu yöntemler potansiyel fayda ve yükleri adalet ilkesi çerçevesinde dă̆ıtmalıdır. Bu makale kısaca dört tahsisat modelini incelemekte ve toplam faydayı en üst düzeye çıkarmak için, sosyal ve etik kabul edilebilirlik, eşitlik ve hakkaniyet paralelinde yeni bir yaklaşım önermektedir. Bu amaca ulaşmak için Kabul Edilebilirlik, Eşitlik ve Hakkaniyet (KEH) modeli altı ilke önerir: a-şsffaflı ve eşit muamele, b-objektif değerlendirme ve denetim, c-devam eden tedavileri sürdürme, $d$-önemli görevleri yerine getiren bireylere öncelik, e-puanlama sistemi ve f-ayn koşullara sahip bireyler için çekiliş. Önerilen model, kaynakların sadece tıbbi gerçeklere değil, ayn zamanda tedavi gören hastalar için devam eden tıbbi prosedürlerin sürdürülmesi gibi sosyal ve etik hususlara dayalı olarak tahsis edilmesini amaçlamaktadır.

Anabtar sözcükler: Pandemi; doğal afetler, kıt kaynaklar, kabul edilebilirlik, eşitlik, hakkaniyet

\section{INTRODUCTION}

As of February 12, 2022, the COVID-19 pandemic has caused about 5,800,000 deaths across the world (1). As fighting the pandemics, many countries, including European countries and the United States, have

\footnotetext{
${ }^{2}$ Dr., Baş Müfettiş, Sağlık Bakanlığı $\bowtie$ avciercan@yahoo.com

Gönderim Tarihi: $04.01 .2022 \bullet$ Kabul Tarihi: 12.02 .2022
} 
experienced serious shortages of certain healthcare resources, like ventilators, intensive care unit (ICU) beds, and vaccines (2). Even though improving healthcare capacity is the most desirable resolution, due to the rapidly increasing number of cases or need for healthcare resources, it may be impossible to meet demand merely by boosting supply (3). Therefore, in the event of pandemics or natural disasters, along with the effort to expand resources, a fair and efficient allocation of scarce resources in healthcare should be implemented based on the principle of justice. However, the interpretation and implementation of justice, during pandemics and natural disasters, might be burdensome because of the number of patients seeking scarce resources.

As highlighted by the Universal Declaration on Bioethics and Human Rights (4), justice is a primary principle in today's bioethical issues. Even though the significance of justice is universally admitted, the question of how to actualize this principle varies (5). Albert R. Jonsen and his colleagues define justice as "moral and social theories that attempt to distribute the benefits and burdens of a social system in a fair and equitable way among all participants in the system" (6, p.167). Through a similar approach, Tom L. Beauchamp and James F. Childress regard justice in healthcare as distributive justice that entails a "fair, equitable, and appropriate distribution of benefits and burdens" (7, p.250). These approaches reveal two imperative points: first, the distribution of benefits and burdens; and second, a fair and equitable distribution. In this context, the current pandemic requires distributing scarce healthcare resources fairly and equitably in the battle against the COVID-19. Nevertheless, the main challenge is about which distribution system or model has a higher potential to fulfill fairness and equity. From this perspective, the paper aims to examine the primary features of four different approaches (American Medical Association's medical approach, the four-categories approach, the six recommendations approach, and the triage-based approach) to the allocation of scarce resources and propose a new model (Acceptability, Equality, and Equity - AEE) to maximize total benefits with social and ethical deliberations.

\section{A MEDICAL APPROACH: AMERICAN MEDICAL ASSOCIATION}

According to the American Medical Association (AMA), the issue of scarce healthcare resources is a big obstacle for physicians to realize their moral responsibilities to maintain and promote patients' wellbeing. Nonetheless, the therapeutic relationship with patients and the commitment to act in the best interest of patients lead physicians to fairly distribute scarce resources among patients. In this context, the AMA suggests developing allocation policies based on "medical need, including urgency of need, likelihood and anticipated duration of benefit, and change in quality of life" $(8, \mathrm{np})$. Furthermore, according to the AMA, applying "an objective, flexible, transparent mechanism to determine which patients will receive the resource(s)" and establishing priorities to prevent "premature death or extremely poor outcomes" are some other criteria to allocate limited resources in a fair manner ( $8, \mathrm{np})$.

Rather than formulating all-inclusive standards or principles, the AMA draws a framework to outline some general recommendations about how to allocate scarce resources, such as ICU beds and ventilators. It may be possible to evaluate this as a physician-oriented and medical assessment-based approach. The framework relates the matter of allocation to physicians' ethical obligation and adopts a resolution according to medical conditions, urgencies, and consequences. However, some argue that the allocation of limited healthcare resources should not be gauged in light of pure medical facts, but also ethical determinants (9). During public health issues, like COVID-19, public justification is an essential point to obtain people's support and trust for/on the implemented policies (10). From this perspective, besides medical reasons, social and ethical motivations could play a critical function in shaping pertinent policies. 


\section{A MULTIDIMENSIONAL APPROACH: FOUR-CATEGORIES}

Lottery, first-come, first-served, sickest first, youngest first, number of lives saved, prognosis, instrumental value, and reciprocity are commonly used principles to determine how to allocate scarce healthcare resources. According to Govind Persad, Alan Wertheimer, and Ezekiel J. Emanuel (9), none of these principles has the capacity to satisfy the ethical challenges and concerns in the distribution of limited resources per se. Persad et al. sort out these principles under four categories: treating people equally, favoring the worst-off, maximizing total benefits, and promoting and rewarding social usefulness, to be able to adopt a multidimensional approach in the allocation of scarce resources.

The first category is treating people equally consisting of lottery and first-come, first-served principles. The main characteristic of these two principles is to treat everyone equally regardless of their medical, social, or economic conditions or status. The second category, favoring the worst-off, is a prioritizing model based on the principles of sickest first and youngest first. The sickest first principle focuses on the possible outcomes and suggests treating the person with the worst prospective consequences if the treatment is not provided. Maximizing total benefits is the third category reflecting the well-known maxim of utilitarianism as 'the greatest good for the greatest number' and comprised of the principles of the number of lives saved and prognosis. The number of lives saved aims to save the greatest number of people when many lives are at risk. On the other hand, the principle of prognosis concentrates on the greatest number of life-years saved among people who need scarce resources. The last category, promoting and rewarding social usefulness, draws attention to social values and shows individuals appreciation for their contribution to society by providing them with certain priorities. This category employs instrumental value that requests giving priority to individuals in the battle against public health issues or conducting vital tasks. The second principle of the fourth category, reciprocity, advocates appreciating individuals' past efforts benefiting the society, such as organ donors and veterans (9).

After assessing the advantages and disadvantages of each category, Persad and his colleagues (9) suggest the complete lives system that relies on the combination of youngest-first, prognosis, lottery, and saving the most lives to allocate scarce healthcare resources and recommend adding instrumental value to these four principles during pandemics.

However, especially the "youngest-first" approach may be considered a discrimination against the elderly (11) and cause increasing social injustice in the communities where people endure the lack of healthcare resources (12). Morally, it is questionable the younger's life has more merit than the elderly's life. Furthermore, according to Samuel J. Kerstein and Greg Bognar, the complete lives system "lacks secure moral foundations and fails to provide meaningful guidance when its component principles conflict" (13, p. 44). From this perspective, even though Govind Persad et al.'s approach addresses a morally more acceptable system than a system relying on a single principle since simultaneously utilizing many principles, it does not demonstrate an ethical flawless proposal due to its abovementioned deficiencies.

\section{THE SIX RECOMMENDATIONS APPROACH}

Ezekiel J. Emanuel et al. (3) elaborate on the four categories and formulate six specific recommendations to fairly allocate limited healthcare resources, such as ICU beds and ventilators, during fighting COVID-19. Emanuel et al. believe that the most appropriate approach in the time of a pandemic is to maximize total benefits that can be achieved through the principles of the number of lives saved and life-years saved. Additionally, they state that the principles of sickest-first and youngest-first may also be utilized to accomplish this goal. In other words, Emanuel et al. advise giving priority to people who can benefit the most to save most lives and life-years. Furthermore, they emphasize that these principles should also be implemented to the patients who have already been receiving scarce resources. Therefore, any limited resources not fulfilling total benefit 
maximization may be withdrawn because the random selection, like first-come, first-served, should not be used during pandemics.

In light of the principle of instrumental value, the second recommendation requests giving priority to healthcare professionals and other individuals who actively take place in the battle against COVID-19 or perform crucial duties. The third recommendation offers a random selection through a lottery when patients seeking limited resources have similar prognoses, as the need for treating people equally. The fourth recommendation suggests differentiating priorities based on interventions and scientific facts. For instance, in the case of vaccination, if available, the elderly should have priority over children due to a higher risk for the elderly, but in the event of allocating an ICU bed or ventilator, younger people with serious conditions should get the priority based on maximizing total benefits. The fifth recommendation advises providing certain priorities with the participants in the relevant research studies, as a reflection of the principle of reciprocity. The sixth recommendation requires distributing scarce resources in accordance with patients' conditions, not diseases. Patients with all kinds of ailments including COVID-19 should be subject to the same allocations criteria (3).

In particular, the fifth recommendation suggesting providing people who participate in research for pertinent vaccines and therapeutics with some priorities carries significant importance in terms of fulfilling justice by fairly distributing benefits and burdens of the system. Giving the research subjects certain priorities may alleviate the concern about the exploitation of vulnerable people and populations, which is a major distress in biomedical research in developing countries (14). Nevertheless, the recommendations do not contain any specifications regarding the relationship or communication among the policymakers, front-line practitioners, and the public. However, as the study conducted by Yeunjae Lee and Jo-Yun Queenie Li denotes, during a pandemic, transparent communication among the relevant stakeholders certainly affects public trust and prompts desirable outcomes (15).

\section{A TRIAGE-BASED APPROACH}

Douglas B. White and his colleagues (16) develop a triage guide to portray primary standards regarding the allocation of limited healthcare resources during public health emergencies. The guide consists of three sections: determining triage teams, deciding allocation criteria, and reevaluating ongoing allocations. Concerning triage teams, White et al. propose appointing acute care physicians as triage officers and, if possible, acute care nurses and administrators as triage team members. According to White et al., in hospitals, triage should be carried out by an acute care physician, if resources available, with an acute care nurse and administrator, to accurately and objectively assess patients' medical conditions as well as to relieve clinicians of the stress and burden resulting from decision-making about allocating limited resources.

In regard to allocation criteria, the fundamental goal is to maximize total benefits by saving the most lives and the most life-years. The system is established on the idea of patient priority scores to achieve the goal. It takes various issues, such as age categories (12-40, 41-60, and 61-75), chronic disease categories (Alzheimer, heart failure, and end-stage renal disease); and prognoses, into consideration to produce a specific priority score for each patient. The scoring system is applied to everyone without any exceptions. However, it recognizes some heightened priorities when yielding individual scores. For example, individuals carrying out indispensable works during public health emergencies get such heightened priorities. Additionally, this triage model employs individual priority scores to create three priority categories: highest priority, intermediate priority, and lowest priority. In the case of ties in priority scores or categories, the model recommends life-cycle considerations, the priority of healthcare professionals, and a lottery consecutively as tiebreakers (16).

The last section of the triage guide is about reevaluating the ongoing provision of limited resources. After allocating scarce resources based on priority scores and categories, the triage committee regularly reassesses 
the patients' medical conditions and decides whether these patients, who are receiving the resources, should sustain them. This reassessment is imperative to maximize total benefits under the circumstance of high demand for pertinent resources. Therefore, the model allows withdrawing ongoing medical treatments when falling short of the goal (16).

Scoring and implementing the system to everyone are the primary advantages of the triage-based approach. However, the requirements for regularly revisiting patients' medical situations and the possibility of ending a continuing treatment based on that assessment are some paramount deficits of this approach. During a public health crisis, frequently reevaluating each patient's medical condition could physically and psychologically exhaust healthcare professionals. Furthermore, like withdrawing emergency medical treatments, weaning a patient from a ventilator, or stopping a patient from using an ICU bed during a pandemic is ethically more problematic than a patient's or surrogate's request to withdraw life-sustaining support (17). Therefore, it is feasible to assert that reassessment and withdrawal of ongoing treatments are neither applicable nor ethical.

\section{A NEW APPROACH: ACCEPTABILITY, EQUALITY, AND EQUITY (AEE) MODEL}

One of the most prevailing features of the above-mentioned approaches is to maximize total benefits by saving the most lives and life-years. As a utilitarian idea, maximizing total benefits during a public health crisis, like COVID-19, could be meaningful and useful. However, pure consequences-based assessments or implementations may not suffice to institute an ethical model. From a justice-driven perspective, the consequences of allocating scarce healthcare resources might be ethically justifiable through acceptable, equal, and equitable standards. However, some features of the abovementioned approaches, such as withdrawing ongoing medical treatments for the sake of maximizing total benefits or designing the system according to pure medical outcomes may overlook ethical and social requirements. For this reason, this paper suggests a new allocation model to maximize total benefits in an acceptable, equal, and equitable manner. The model does not merely rely on medical facts but also social and ethical considerations through six principles as follows:

a- Transparency and Equal Treatment: Public health crises, such as pandemics and natural disasters, refer to oppressive periods that may cause panic among individuals and distrust in the relationship between individuals and authorities. An essential method to eliminate or minimize fear and insecurity in society is to consider the public a major stakeholder and share the available information with them because "transparency requires openness and sharing of information in ways that are accessible and understandable to stakeholders" $(18$, p.11). In this view, the authority performing public health services should inform people accurately and thoroughly about the taken precautions and provided services, including scarce resources-related policies. The significance of transparency is twofold: firstly, it gives individuals to access information; secondly, it is an appropriate way to obtain public support for the pertinent policies, precautions, and implementations, which many times restrict individual liberty and prompt a public outcry.

In addition to transparency, equal treatment is another critical matter to earn public trust. During a period when people carry various concerns for the wellbeing of themselves and their loved ones, individuals who need scarce healthcare resources should ensure that they will not encounter any injustices. Therefore, the rules, principles, or criteria determined by allocation models should be applied to everyone without any exceptions. In this sense, equal treatment can secure that nobody gets undue priorities or is deprived of resources on the grounds of social, economic, or political reasons.

Another requirement of equal treatment, during public health emergencies, is to implement determined allocation rules or models for all healthcare institutions without any distinction between public and private organizations to institute a sense of equality and equity at the social level. 
b- Priority to Individuals Performing Crucial Tasks: Individuals who play a vital role in the battle against pandemics, like COVID-19, should have priority in accessing limited resources, as per instrumental value. Giving priority to individuals showing such a strong commitment to benefitting society will relieve these people of the concerns regarding their health if they get sick. Moreover, priority to access scarce treatments would help them recover from the disease and allow them to return to their jobs that remarkably benefit society. Additionally, giving priority to these people is a recognition and appreciation of their invaluable work and sacrifice.

c- Objective Assessment and Supervision: Objectivity in this principle refers to deciding based on scientific facts as well as acting impartially. Any allocation model aiming to maximize total benefits needs to propose particular criteria to evaluate patients' current medical conditions, medical histories, prognoses, and the medical results of ongoing treatments. In this context, both prior to distributing limited healthcare resources and during ongoing treatments an objective assessment should be made by qualified officers. Furthermore, the decisions and applications should be supervised by a committee that is comprised of diverse experts to ensure the public that the system is running and overseen objectively. This principle would also allow healthcare professionals to devote their knowledge, experience, and attention to patients' treatments and prevent them from encountering unfair priority requests.

d- Sustaining Ongoing Treatments: The matter of distinction between withholding and withdrawing medical procedures is an ethical debate, especially in end-of-life issues (19). Even though it is possible to state various arguments about this discussion, I believe that after beginning to provide medical interventions, including scarce resources in pandemics, they should be withdrawn only under limited circumstances: the patient rejects the treatment; the patient no longer needs the treatments (recovery); or there is clear evidence that the treatment is medically futile. Except for these three situations, withdrawing a medical procedure, containing ventilators and ICU beds, would not be ethically acceptable and equitable. A salient advantage of maintaining ongoing treatments is to prevent healthcare professionals from the emotional distress and ethical dilemmas in the case of deciding about withdrawing the ongoing treatment.

e- Scoring System: During public health emergencies, maximizing total benefits is the most reasonable and defensible argument. For achieving this, a priority scoring system should be established through the combination of three principles: sickest first, youngest first, and prognosis. The total score of the three principles should form the patient's priority score. When scoring, the principles may be valued equally, or depending on medical or social preferences, a principle could be attributed to a higher score than the others. However, the system should have consistency without applying different scoring systems to different patients. Additionally, it is important to note that the scoring system should be carried out based on patients, not disease and disease sources. For instance, a patient suffering from respiratory distress due to COVID-19 and a patient with chronic lung disease should be subject to the same scoring system in the allocation of mechanical ventilation.

f- Lottery for Individuals with the Same Conditions: While distributing scarce resources among individuals conducting vital tasks during public health emergencies or individuals having the same priority scores, as per equal treatment, the allocation should be determined through a lottery. For example, under the availability of an ICU bed, if two healthcare professionals are on duty during COVID-19, the selection should be made randomly through the lottery. 
Table 1: The Framework of the Acceptability, Equality, and Equity (AEE) Model

\begin{tabular}{|c|c|c|c|c|}
\hline \multicolumn{5}{|c|}{$\begin{array}{l}\text { Aim: Maximizing total benefits in the allocation of scarce healthcare resources during pandemics and natural } \\
\text { disasters in an acceptable, equal, and equitable manner }\end{array}$} \\
\hline Principle & Requirements & Advantages & Relevant Value & Risks \\
\hline $\begin{array}{l}\text { 1- } \\
\text { Transparency } \\
\text { and Equal } \\
\text { Treatment }\end{array}$ & $\begin{array}{l}\text { - Instituting a transparent } \\
\text { mechanism } \\
\text { - Applying the rules to } \\
\text { everyone without any } \\
\text { exceptions } \\
\text { - Implementing the rules } \\
\text { to both public and private } \\
\text { healthcare institutions }\end{array}$ & $\begin{array}{l}\text { - Allowing people to access } \\
\text { information } \\
\text { - Letting people know how the } \\
\text { system works } \\
\text { - Obtaining public support for } \\
\text { the allocation system } \\
\text { - Treating people equally } \\
\text { - Building public trust } \\
\text { - Avoiding private healthcare } \\
\text { institutions-based injustice }\end{array}$ & $\begin{array}{l}\text { - Acceptability } \\
\text { - Equality }\end{array}$ & $\begin{array}{l}\text { - Intervening } \\
\text { in the liberty } \\
\text { of private } \\
\text { healthcare } \\
\text { organizations }\end{array}$ \\
\hline $\begin{array}{l}\text { 2- Objective } \\
\text { Assessment } \\
\text { and } \\
\text { Supervision }\end{array}$ & $\begin{array}{l}\text { - Objectively evaluating, } \\
\text { determining, and supervising } \\
\text { patients' medical situations }\end{array}$ & $\begin{array}{l}\text { - Deciding based on scientific } \\
\text { considerations and medical } \\
\text { facts } \\
\text { - Ensuring the public that the } \\
\text { assessment of allocations is } \\
\text { made objectively } \\
\text { - Overseeing the decisions } \\
\text { impartially } \\
\text { - Preventing healthcare } \\
\text { professionals from unfair } \\
\text { priority requests }\end{array}$ & $\begin{array}{l}\text { - Acceptability } \\
\text { - Equality }\end{array}$ & $\begin{array}{l}\text { - The pressure } \\
\text { (external) } \\
\text { and stress } \\
\text { (internal) that } \\
\text { the healthcare } \\
\text { professionals } \\
\text { who make the } \\
\text { assessment and } \\
\text { supervision may } \\
\text { face }\end{array}$ \\
\hline $\begin{array}{l}\text { 3- Sustaining } \\
\text { Ongoing } \\
\text { Treatments }\end{array}$ & $\begin{array}{l}\text { - Withdrawing medical } \\
\text { intervention only under } \\
\text { limited conditions }\end{array}$ & $\begin{array}{l}\text { - Differentiating withdrawing } \\
\text { medical intervention from } \\
\text { withholding during pandemics } \\
\text { and natural disasters } \\
\text { - Preventing healthcare } \\
\text { professional from emotional } \\
\text { distress and ethical dilemmas }\end{array}$ & - Acceptability & $\begin{array}{l}\text { - Consequences } \\
\text { against } \\
\text { maximizing total } \\
\text { benefits }\end{array}$ \\
\hline $\begin{array}{l}\text { 4- Priority to } \\
\text { Individuals } \\
\text { Performing } \\
\text { Crucial Tasks }\end{array}$ & $\begin{array}{l}\text { - Giving priority to } \\
\text { individuals who are in the } \\
\text { battle against the pandemic } \\
\text { or natural disaster or produce } \\
\text { vital services in this period }\end{array}$ & $\begin{array}{l}\text { - Relieving the individuals of } \\
\text { the concerns regarding their } \\
\text { wellbeing } \\
\text { - Helping them recover from } \\
\text { the disease and return their jobs } \\
\text { as soon as possible } \\
\text { - Recognizing and appreciating } \\
\text { these individuals invaluable } \\
\text { work and sacrifice }\end{array}$ & $\begin{array}{l}\text { - Acceptability } \\
\text { - Equity }\end{array}$ & $\begin{array}{l}\text { - The process of } \\
\text { deciding what is } \\
\text { vital, what is not }\end{array}$ \\
\hline $\begin{array}{l}\text { 5- Scoring } \\
\text { System }\end{array}$ & $\begin{array}{l}\text { - Scoring each patient's } \\
\text { priority based on the } \\
\text { principles of sickest first, } \\
\text { youngest first, and prognosis } \\
\text { - Applying the scoring system } \\
\text { to all patients, not only } \\
\text { patients with COVID-19 }\end{array}$ & $\begin{array}{l}\text { - Using not a single principle, } \\
\text { but the combination of three } \\
\text { principles } \\
\text { - Having flexibility in the } \\
\text { weight of each principle in the } \\
\text { totality } \\
\text { - Treating all patients equally }\end{array}$ & $\begin{array}{l}\text { - Equity } \\
\text { - Equality }\end{array}$ & $\begin{array}{l}\text { - Unique } \\
\text { situations that } \\
\text { sickest first, } \\
\text { youngest first, } \\
\text { and prognosis } \\
\text { fall short to } \\
\text { create equity }\end{array}$ \\
\hline $\begin{array}{l}\text { 6- Lottery for } \\
\text { Individuals } \\
\text { with the Same } \\
\text { Conditions } \\
\end{array}$ & $\begin{array}{l}\text { - Allocating scarce resources } \\
\text { among patients with the same } \\
\text { situations through a lottery }\end{array}$ & $\begin{array}{l}\text { - Applying easily } \\
\text { - Not requiring any assessments } \\
\text { (random selection) }\end{array}$ & - Equality & $\begin{array}{l}\text { - Causing } \\
\text { inequitable } \\
\text { situations }\end{array}$ \\
\hline
\end{tabular}


As the Table 1 demonstrates, each principle carries certain requirements, values, advantages, and risks. In particular, the first three principles, (transparency and equal treatment, objective assessment and supervision, and sustaining ongoing treatments) draw attention to the ethical aspect of the allocation by underscoring the necessity for transparency, equality, and objectivity that can help to increase and maintain public support and trust in the governance of pandemics and natural disasters. As some studies accentuate, public trust is significantly important to handle public health crises (20). Additionally, in regard to the continuity of treatments, withdrawing an ongoing treatment is ethically and religiously questionable and extremely stressful for family members and healthcare professionals $(21,22)$. Therefore, besides the practical features of the model, such as prioritizing, scoring, and lottery, formulating a transparent, equal, and objective system with ethical and social concerns would generate a fairer framework for scarce health resources. From this perspective, in light of the six principles, the AEE model aims to maximize total benefits when actualizing the public acceptability of the allocation system, disturbing the benefits and burdens of public health policies equally to individuals and groups with the same situations, and spotlighting the different needs and conditions of people and populations to accomplish a morally justifiable structure.

\section{CONCLUSION}

Applying a fair allocation model in the distribution of scarce healthcare resources is a requirement of the principle of justice. During public health emergencies, due to exceedingly high demand for certain resources, such as ventilators, ICU beds, and vaccines, fulfilling justice becomes more demanding and challenging. Four different approaches were examined to explore distinct perspectives on the distribution of limited resources. The findings revealed that the goal to maximize total benefits is the common point of all the approaches, and sickest first, youngest first, number of lives saved, prognosis, instrumental value, and lottery are dominant principles to fulfill this goal. Even though each approach carries various merits, there is a need for drawing a new perspective to emphasize the necessity of social and ethical determinants in the allocation of scarce resources. For this reason, this paper proposes the AEE model to maximize total benefits with social and ethical considerations through six principles as illustrated by Table 1. Even though the AEE model profits from the examined four approaches, it emphasizes the significance of formulating a transparent system to build public trust, implementing objective criteria and sustaining ongoing treatments to promote social and ethical acceptance, giving priority to frontline fighters to fulfill fairness, and treating everyone who carries similar condition the same to generate an equal public health model.

\section{REFERENCES}

1. Johns Hopkins University [Internet]. COVID-19 Data Center [cited 2022 February 12]. Available from: https:// coronavirus.jhu.edu/map.html.

2. Schoch-Spana M, Brunson EK, Gwon H, Regenberg A, Toner ES, Daugherty-Biddison EL. Influence of community and culture in the ethical allocation of scarce medical resources in a pandemic situation: deliberative democracy study. Journal of Participatory Medicine 2020;12(1):e18272. [Doi]

3. Emanuel EJ, Persad G, Upshur R, Thome B, Parker M, Glickman A, Zhang C, Boyle C, Smith M, Phillips JP. Fair allocation of scarce medical resources in the time of covid-19. N Engl J Med 2020;382(21):2049-2055. [Doi]

4. UNESCO. Universal declaration on bioethics and human rights [cited 2022 January 5]. Available from: http:// portal.unesco.org/en/ev.php-URL_ID=31058\&URL_DO=DO_TOPIC\& URL_SECTION=201.html.

5. Daniels N. Justice, health, and healthcare. Am J Bioeth 2001 Spring;1(2):2-16. [Doi]

6. Jonsen AR, Siegler M, Winslade WJ. Clinical ethics: a practical approach to ethical decisions in clinical medicine 8th ed. New York: McGraw-HillEducation; 2015.

7. Beauchamp TL, Childress JF. Principles of biomedical ethics. 7th ed. New York: Oxford University Press; 2013. 
8. American Medical Association. Allocating limited health care resources [cited 2022 January 5]. Available from: https://www.ama-assn.org/delivering-care/ethics/allocating-limited-health-care-resources.

9. Persad G, Wertheimer A, Emanuel EJ. Principles for allocation of scarce medical interventions. Lancet 2009;373(9661):423-31. [Doi]

10. Childress JF, Faden RR, Gaare RD, Gostin LO, Kahn J, Bonnie RJ, Kass NE, Mastroianni AC, Moreno JD, Nieburg P. Public health ethics: mapping the terrain. J Law Med Ethics 2002;30(2):170-8. [Doi]

11. Wareham CS. Youngest first? Why it is wrong to discriminate against the elderly in healthcare. S Afr J BL 2015;8(1):37-39. [Doi]

12. Sayeed SA. Assessing the modified youngest-first principle and the idea of non-persons at the bedside: a clinical perspective. The American Journal of Bioethics 2010;10(4):52-54.

13. Kerstein SJ, Bognar G. Complete lives in the balance. The American Journal of Bioethics 2010;10(4):37-45. [Doi]

14. Ballantyne AJ. How to do research fairly in an unjust world. The American Journal of Bioethics 2010;10(6):26-35. [Doi]

15. Lee Y, Li JQ. The role of communication transparency and organizational trust in publics' perceptions, attitudes and social distancing behaviour: a case study of the COVID-19 outbreak. J Contingencies and Crisis Management 2021;29:368-384.

16. White DB, Katz M, Luce J, Lo B. Allocation of scarce critical care resources during a public health emergency. University of Pittsburgh Department of Critical Care Medicine; 2020 [cited 2022 January 5]. Available from https://ccm.pitt.edu/sites/default/files/UnivPittsburgh_ModelHospitalResourcePolicy_2020_04_15.pdf.

17. Iserson KV. Withholding and withdrawing medical treatment: an emergency medicine perspective. Annals of Emergency Medicine 1996;28(1):51-54.

18. National Academies of Sciences, Engineering, and Medicine. Human genome editing: science, ethics, and governance. Washington, DC: The National Academies Press; 2017. [Doi].

19. Lo B. Resolving ethical dilemmas: a guide for clinicians. $6^{\text {th }}$ ed. Philadelphia: Wolters Kluwer; 2020.

20. Han Q, Zheng B, Cristea M, Agostini M, Bélanger JJ, Gützkow B, Kreienkamp J; PsyCorona Collaboration, Leander NP. Trust in government regarding COVID-19 and its associations with preventive health behaviour and prosocial behaviour during the pandemic: a cross-sectional and longitudinal study. Psychol Med 2021;26:1-11. [Doi]

21. Olsen ML, Swetz KM, Mueller PS. Ethical decision making with end-of-life care: palliative sedation and withholding or withdrawing life-sustaining treatments. Mayo Clin Proc 2010;85(10):949-54. [Doi].

22. Ankeny RA, Clifford R, Jordens CF, Kerridge IH, Benson R. Religious perspectives on withdrawal of treatment from patients with multiple organ failure. Med J Aust. 2005;183(11-12):616-21. [Doi] 